\title{
Characterization and in vitro antitumor activity of polymeric nanoparticles loaded with Uncaria tomentosa extract
}

\author{
ANA F. RIBEIRO, JULIANA F. SANTOS, RÔMULO R. MATTOS, ELIANE G.O. BARROS, \\ LUIZ EURICO NASCIUTTI, LÚCIO M. CABRAL \& VALERIA P. DE SOUSA
}

\begin{abstract}
Uncaria tomentosa (UT) extracts have been shown to have promising antitumor activity. We hypothesized that its incorporation into nanostructured systems could improve the anticancer properties. Here, poly-e-caprolactone (PCL) and poly-d,l-lactideco-glycolide (PLGA) were employed to generate nanoparticles loaded with UT extract in a single emulsion solvent evaporation method. The nanoparticles were characterized by particle size, zeta potential, morphology and entrapment efficiency along with stability and release profiles. The nanoparticles presented entrapment efficiencies above $60 \%$ and a mean diameter below 300nm. UT-PCL nanoparticles presented higher entrapment efficiency and mean particle size as well as a slow release rate. The UT-PLGA nanoparticles showed higher drug loading. Two prostate cancer cell-lines, LNCaP and DU145 that were derived from metastatic sites, served as model systems to assess cytotoxicity and anticancer activity. In vitro, both formulations reduced the viability of DU145 and LNCaP cells. Yet, the UT-PLGA nanoparticles showed higher cytotoxicity towards DU145 cells while the UTPCL against LNCaP cells. The results confirm that the incorporation of UT into nanoparticles could enhance its anti-cancer activities that can offer a viable alternative for the treatment of prostrate canner and highlights the potential of nanostructured systems to provide a promising methodology to enhance the activity of natural extracts.
\end{abstract}

Key words: Nanoparticles, prostate cancer, PLGA, PCL, anti-tumor, anti-cancer, Cat's Claw.

\section{INTRODUCTION}

Uncaria tomentosa (UT) is a vine plant found in the Peruvian Amazon, commonly known as "cat's claw", whose bark has been known to be used in a variety of popular therapeutic preparations (Heitzman et al. 2005). A review of the literature reveals several pharmacological activities of UT, which includes an anti-tumor activity. Different UT extracts have been reported to have in vitro effects on a wide range of cancer cell lines (Fazio et al. 2008, Pilarski et al. 2010). Using animal models, a number of studies have further indicated that plant extracts display promising anti-cancer activities (Pilarski et al. 2010, Dreifuss et al. 2010, Miranda \& Freitas 2008). The results from a clinical trial conducted by Araújo et al. (2012) suggested that a dried hydroalcoholic extract of UT could be considered an effective adjuvant treatment to breast cancer based on a reduction in the neutropenia caused by chemotherapy and a protective effect for DNA.

The anti-tumor activity of UT extract has been mainly attributed to the presence of pentacyclic oxindole alkaloids (POAs; Figure 1), principally as mitraphylline (Giménez et al. 2010, 
Prado et al. 2007). In addition, some POAs appear to be less toxic to nonmalignant cells, which confers a higher tumor selectivity (Kaiser et al. 2016). Importantly, a synergic action from the presence of different plant-derived compounds appears to be responsible for the anti-tumor action of UT rather than any single compound (Pilarski et al. 2010, Dreifuss et al. 2013).

Currently, the American Cancer Society estimates that nearly 2 million new cancer cases are reported yearly with greater than 600,000 deaths attributable to cancer in the United States. Among American men, prostate cancer $(P C)$ is the most frequent, non-skin cancer that represents the third most common cause of death in men (Siegel et al. 2017). A number of human PC cell lines have been derived from different metastatic sites that have successfully served as in vitro PC models by researchers worldwide for understanding mechanisms underlying various aspects of PC (Russell \& Kingsley 2003). Two cell lines that represent different spectrums of PC progression are LNCaP and DU145. The progenitor cells of LNCaP were derived from a lymph node metastasis that express a mutated androgen receptor and the prostate-specific antigen (Veldscholte et al. 1990). They are androgen-dependent and display a relatively indolent biologic behavior. In contrast, the DU145 cell line is derived from a brain metastasis in a case of human PC and are androgen-independent cells that show a more aggressive behavior compared to LNCaP cells (Stone et al. 1978). These two human PC cell lines have also been used to investigate the anti-tumor properties of natural compounds and extracts (Medjakovic et al. 2016, Park et al. 2016, Rao et al. 2004, Zhang et al. 2008). In some cases, compounds have shown distinct inhibition potency that depends on which cell line is under study (Park et al. 2016, Rao et al. 2004).
For plants from the genus Uncaria, the antitumor activity of extracts from some species have been studied in PC cell lines. The aqueous extract of Uncaria rhychophylla, for example, was able to inhibit the growth of PC-3 cells, but not LNCaP cells (Shoemaker et al. 2005). An antitumor effect of Uncaria guianensis has already been demonstrated in DU145 cells. In this case, the POA were considered the main components responsible for the anti-tumor activity (Lee et al. 1999). Another study provided evidence that Uncaria guianensis has some cytostatic effect on PC-3 cells (Urdanibia et al. 2013). Moreover, the POA of Uncaria tomentosa, with the exception of mitraphylline, inhibited the growth of PC-3 cells, with isopteropodine and pteropodine proving to be the most potent alkaloids (Fujita et al. 2009).

The loading of natural products into nanostructured systems have been widely studied since nanoparticles can optimize beneficial properties that improve the activity of natural compounds and extracts (Bonifacio et al. 2014). Polymeric nanoparticles are nanostructured systems extensively used for the nanoencapsulation of various active compounds. Biodegradable polymers, such as poly-e-caprolactone (PCL) and poly-d,l-lactideco-glycolide (PLGA), are the most common polymers used to obtain nanoparticles, due mainly to their biocompatibility and sustained release properties (Kumari et al. 2010). Yet, for the same encapsulated drug, each of these polymers can generate nanoparticles with different physicochemical properties and distinct in vitro release profiles that require empirical evaluations (Ubrich et al. 2004).

When applied to natural agents with antitumor properties, considerable advantages can be realized by nanoparticles for cancer treatment (Bharali et al. 2011, Kumari et al. 2016). A major advantage is passive targeting, 
which allows nanoparticles to permeate and accumulate in tumors since their tissues have blood vessels with larger fenestrations due to angiogenesis and an ineffective lymphatic drainage. This process enables a reduction in side effects and an improvement in the therapeutic effects (Kumari et al. 2016, Singh \& Lillard Jr. 2009, Sultana et al. 2013). Previous studies with nanoparticles loaded with natural compounds, such as epigallocatechin-3-gallate (EGCG), resveratrol and curcumim, demonstrated a promising potential through their activity against PC cell lines (Sanna et al. 2013). A more recent study with $\mathrm{PCL}$-based nanoparticles loaded with celastrol, a triterpenoid extracted from the Tripterygium wilfordii, also showed anti-proliferative activity on LNCaP, DU145 and PC-3 cell lines (Sanna et al. 2015).

In this work, nanoparticles loaded with UT extracts were generated with two different polymers ( $P C L$ and PLGA). The physicochemical properties of the nanostructured systems were characterized along with their in vitro release profiles. To evaluate the potential of these formulations for the treatment of PC in humans, their anti-tumor activity was tested against LNCaP and DU145 cell lines.

\section{MATERIALS AND METHODS}

\section{Materials}

Uncaria tomentosa dried extract ( $4.5 \%$ of total pentacyclic oxindole alkaloids) was kindly donated by Herbarium Laboratório Botânico (PR, Brazil). Poly-e-caprolactone (PCL; Mw 70,000-90,0000 g/mol), polyvinyl alcohol (PVA; Mw 31,000-50,000 g/mol, 87-89\% hydrolyzed) and cellulose dialysis membranes (flexible tube type, 33 mm, 14 kDa MWCO) were obtained from Sigma-Aldrich (MO, USA). Poly-d,l-lactide-coglycolide (PLGA), with 50:50 D,L-lactide:glycolide molar ratio and intrinsic viscosity of $0.45-0.60$ $\mathrm{dl} / \mathrm{g}$ (Resomer ${ }^{\circledR} \mathrm{RG}$ 504), was purchased from Boehringer Ingelheim (RP, Germany) and poloxamer 188 (Lutrol ${ }^{\circledR}$ F68, Mw 7680-9510 Da) from BSAF (RP, Germany). Methylene chloride, ethyl acetate, acetone and ethanol were acquired from Tedia Brazil (RJ, Brazil).

\section{Cell culture}

The DU145 androgen-insensitive human PC cell line and the LNCaP androgen-sensitive human PC cell line were obtained from the Cell Bank of Rio de Janeiro. Cultures were maintained in RPMI 1640 (Gibco) medium supplemented with 10\% fetal bovine serum (FBS), 100 units $/ \mathrm{mL}$ penicillin and $100 \mathrm{mg} / \mathrm{mL}$ streptomycin in a $5 \%$ $\mathrm{CO} 2$ humidified environment at $37^{\circ} \mathrm{C}$.

\section{Preparation of nanoparticles}

Solutions of ethyl acetate and acetone containing the UT extract were prepared by dispersing $1 \mathrm{~g}$ of dried UT extract into $50 \mathrm{~mL}$ of each organic solvent. Mixtures were sonicated for $20 \mathrm{~min}$ and filtered using a $0.45 \mathrm{~mm}$ membrane. The alkaloid content in each was determined by HPLC using a Perkin Elmer C18 column (150 x $4.6 \mathrm{~mm}, 3 \mathrm{~mm}$ ) (SP, Brazil) coupled to a diode array detector L-2455 (Merck Hitachi Lachrom Elite ${ }^{\circledR}$, Hitachi High Technologies America, CA, USA). A previously validated gradient method was employed for the separation process under a $0.8 \mathrm{~mL} / \mathrm{min}$ flow rate and detection at $245 \mathrm{~nm}$ (Bertol et al. 2012).

Polymeric nanoparticles were prepared by an oil-in-water single emulsion solvent evaporation method, based on optimized methods described previously (Ribeiro et al. 2013, 2015). An organic phase was prepared by dissolving polymer, either PLGA or PCL, in $5 \mathrm{~mL}$ of an ethyl acetate/acetone mixture at a 3:2 ratio containing UT extract with $\sim 1.4 \mathrm{mg}$ of total alkaloid content. Next, the organic phase was added dropwise to a buffered aqueous phase 
(pH 7.5) containing a surfactant (Poloxamer 188 or PVA) that was emulsified by constant stirring and sonication at $100 \mathrm{~W}$ in an ice bath $\left(\mathrm{UP} 100 \mathrm{H}^{\circledR}\right.$ ultrasonic processor, Hielscher, BB, Germany). Organic solvents were removed by evaporation under reduced pressure that also drove precipitation of the nanoparticles. Unloaded (blank) nanoparticles were prepared using the same process in the absence of the UT extract. A control solution of UT extract was also prepared using the emulsion-solvent evaporation method without polymer in the organic phase that yielded an aqueous solution with an alkaloid composition identical to the initial alkaloid composition added to the nanoparticle system. It presented an alkaloid concentration around $200 \mathrm{mg} / \mathrm{mL}$, since the surfactant added to the aqueous phase improved the alkaloids solubility in water. Table I summarizes the conditions used in the preparation of each formulation.

\section{Size distribution, zeta potential and morphology}

Size distribution and zeta potential were determined using a Malvern ZetaSizer ZS ${ }^{\circledR}$ (Malvern Instruments, WO, UK). Mean diameter and polydispersity index (PI) measurements were obtained by dynamic light scattering (DLS) following a 1:10 dilution of the nanoparticles in purified water. The surface potential of nanoparticle suspensions was measured without dilution.

For morphological analysis, suspensions were placed onto 200 mesh carbon-coated grids and covered with uranium acetate $5 \%$ for 10 minutes. Samples were completely dried before the analysis by transmission electron microscopy (Zeiss EM $900{ }^{\circledR}$, Carl Zeiss Microscopy GmbH, TH, Germany).

\section{Entrapment efficiency and drug loading coefficient}

Entrapment efficiency (EE) was determined by an indirect method. Nanoparticle suspensions were centrifuged ( $150,000 \times$ g for 30 minutes). The

Table I. Conditions used in the preparation of polymeric nanoparticles and UT extract aqueous solution.

\begin{tabular}{|c|c|c|c|c|c|c|}
\hline \multirow{2}{*}{ 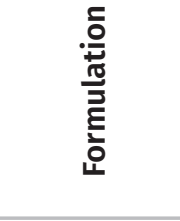 } & \multicolumn{3}{|c|}{ Organic Phase } & \multicolumn{3}{|c|}{ Aqueous Phase $^{2}$} \\
\hline & $\begin{array}{l}\text { Polymer } \\
\text { type }\end{array}$ & $\begin{array}{l}\text { Polymer } \\
\text { amount } \\
\text { (mg) }\end{array}$ & Solvent mixture ${ }^{1}$ & $\begin{array}{l}\text { Volume } \\
\text { (mL) }\end{array}$ & $\begin{array}{c}\text { Surfactant } \\
\text { type }\end{array}$ & $\begin{array}{c}\text { Surfactant } \\
\text { concentration } \\
(\mathrm{w} / \mathrm{v})\end{array}$ \\
\hline Np PCL & $P C L$ & 150 & $E A / A C$ & 8.5 & PVA & $1.0 \%$ \\
\hline Np UT-PCL & PCL & 150 & EA-UT / AC-UT* & 8.5 & PVA & $1.0 \%$ \\
\hline Np PLGA & PLGA & 58 & $E A / A C$ & 7.0 & Poloxamer 188 & $0.5 \%$ \\
\hline Np UT-PLGA & PLGA & 58 & EA-UT / AC-UT* & 7.0 & Poloxamer 188 & $0.5 \%$ \\
\hline UT Sol & - & - & EA-UT / AC-UT* & 7.0 & Poloxamer 188 & $0.5 \%$ \\
\hline
\end{tabular}

'Proportion of solvent mixture: $3 \mathrm{~mL}$ of ethyl acetate (EA) and $2 \mathrm{~mL}$ of acetone (AC), with or without UT extract; *20 mg/mL of UT extract for each solvent ( $1.4 \mathrm{mg}$ of total alkaloids in the $5 \mathrm{~mL}$ of the solvents mixture); ${ }^{2}$ Phosphate buffer $\mathrm{pH}=7.5$. 
supernatant was removed and filtered through a $0.45 \mathrm{~mm}$ membrane for injection into the HPLC system as described above. The mass of total alkaloids in the supernatant (Wsupernatant) was determined to calculate the mass of drug not included into the nanoparticles. Therefore, the loaded mass of alkaloids was determined by the difference between the initial mass of total alkaloids added to the system (Winitial) and the mass of total alkaloids in the supernatant. Entrapment efficiency and drug loading coefficient (DL) were calculated using the equations 1 and 2, respectively. DL was used to evaluate the relationship between the loaded mass of alkaloids and the mass of polymer (Wpolymer) added to the formulations (Stecanella et al. 2013).

$$
\begin{aligned}
& E E=\frac{W_{\text {initial }}-W_{\text {supernatant }}}{W_{\text {initial }}} \times 100(\%) \\
& D L=\frac{W_{\text {initial }}-W_{\text {supernatant }}}{W_{\text {polymer }}} \times 100(\%) \\
& \text { Nanoparticles in vitro stability }
\end{aligned}
$$

Nanoparticles suspensions were kept at $25^{\circ} \mathrm{C}$ for up to 27 days. During this period, the particles mean diameter and polydispersity index were measured by DLS as described above after a 1:10 dilution in purified water.

\section{In vitro release study}

A dialysis bag diffusion technique was used to evaluate the alkaloid release profile from nanoparticles. Cellulose dialysis membranes (flexible tube type) were boiled in purified water for 10 minutes prior to forming bags. Suspensions of nanoparticles of PCL with UT extract (Np UTPCL) or nanoparticles of PLGA with UT extract (Np UT-PLGA) were added and the bag closed before immersion in $30 \mathrm{~mL}$ of phosphatebuffered saline solution (PBS). Ethanol was added to the PBS solution to a concentration of $10 \% \mathrm{v} / \mathrm{v}$ to ensure alkaloid solubility. The release medium was kept under constant stirring in a water bath at $37 \pm 1^{\circ} \mathrm{C}$ for up to 35 days. At specific time intervals, a sample (3 $\mathrm{mL}$ ) was withdrawn and replaced with an equal volume of fresh release medium to maintain sink conditions. Collected samples were filtered through a $0.45 \mathrm{~mm}$ membrane for injection into the HPLC system as described above.

\section{Cell viability assay}

Suspensions of Np UT-PCL and Np UT-PLGA were sterilized by filtration through a 0.45 $\mathrm{mm}$ membrane and added to DMEM medium supplemented with $10 \%$ FBS at a volume ratio of 1:10 for testing the in vitro anti-tumor activity against the PC cell lines LNCaP and DU145. Blank nanoparticles (Np PCL and Np PLGA) and the UT control solution (UT Sol) were sterilized and diluted in the culture medium in exactly the same way as UT nanoparticles. In addition, UT Sol was used at five different concentrations of alkaloids (40 to $200 \mathrm{mg} / \mathrm{mL}$ ), which were diluted in culture medium at a ratio of 1:10 and resulted in concentrations ranging from 4.0 to $20.0 \mathrm{mg} /$ $\mathrm{mL}$. Aqueous buffers ( $\mathrm{pH} 7.5)$ with PVA (1.0\% w/v; PVA Sol) and poloxamer 188 (0.5\% w/v; Lutrol Sol) were also prepared, sterilized and diluted in DMEM to verify the influence of the nanoparticles aqueous phase on the cell viability.

As an index of cell viability, we used a commercially available 3-(4,5-dimethylthiazol2-yl)-2,5-diphenyltetrazolium bromide (MTT) assay to determine the number of viable cells according to the manufacturer's recommendations (Sigma-Aldrich). Briefly, 1×104 LNCaP cells or DU145 cells were seeded into a 24-well cell culture plate and incubated for $24 \mathrm{~h}$ with $500 \mu \mathrm{L}$ RPMI+FBS. Next, cells were washed and treated with the nanoparticles or controls (Np UT-PCL, Np UT-PLGA, Np PCL, Np PLGA or UT 
Sol, PVA Sol, Lutrol Sol) in culture medium for up to 72 hours. After treatments, a $0.5 \mathrm{mg} / \mathrm{mL}$ MTT solution was added. Following a $4 \mathrm{~h}$ incubation at $37^{\circ} \mathrm{C}$, dimethyl sulfoxide was added, cells lysed and the MTT product measured at 570 $\mathrm{nm}$ in a spectrophotometer (Bio-Rad iMARKE, Hercules, CA, USA). The effect of each sample (treatment) on cellular survival was expressed as percentage of cell viability of LNCaP and DU145 cells measured under untreated, control condition, which was considered $100 \%$ viability. All assays were performed in three independent experiments and in sextuplicate.

\section{Statistical analysis}

All experiments were performed at least in triplicate and statistical analysis was performed using GraphPad Prism ${ }^{\circledR}$ version 5.0 (GraphPad Software, CA, USA). Significance of the differences between means was analyzed by the Student's t-test when comparing two means and by analysis of variance (ANOVA) when comparing more than two means $(a=0.05)$.

\section{RESULTS AND DISCUSSION}

\section{Nanoparticles characterization}

The entrapment efficiency (EE) and in vitro release calculations were taken using the sum of the six alkaloids areas found in the HPLC chromatogram of the UT extract, corresponding to the POAs speciophylline, uncarine $F$, mitraphylline, isomitraphylline, pteropodine and isopteropodine (Figure 1). For both formulations, Np UT-PCL and Np UT-PLGA, the entrapment efficiencies for the total alkaloids presented above 60\% (Table II). Np UT-PLGA showed a lower EE along with a significantly higher drug loading (DL) compared to Np UTPCL. This suggested that a lower polymer mass was needed for entrapment of the alkaloids into
PLGA nanoparticles. PLGA Resomer ${ }^{\circledR}$ RG 504 has acidic groups that can interact with any basic amino groups present in alkaloids structure (Ubrich et al. 2004), which could contribute to the higher drug loading of the UT POA in Np UT-PLGA.

The pKa values of UT POA may have directly influenced the entrapment of each alkaloid into nanoparticles. Different EE values were found for each UT POA in both PCL and PLGA matrixes (Table III). Isopteropodine has the lowest pKa value among the UT POA (Stuppner et al. 1992) and is maintained mostly in its non-ionized form in nanoparticles in the aqueous phase $\mathrm{pH}$ of 7.5, which should favor its interaction with the hydrophobic polymer matrixes. Moreover, the POA ionization degree seems to exert greater influence on the interaction with PLGA than

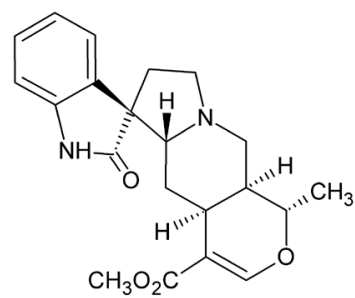

(1) Speciophylline

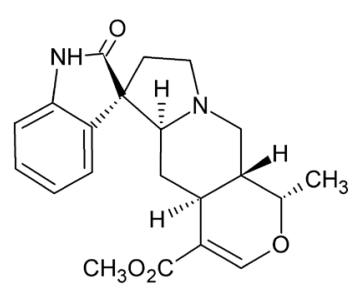

(3) Mitraphylline

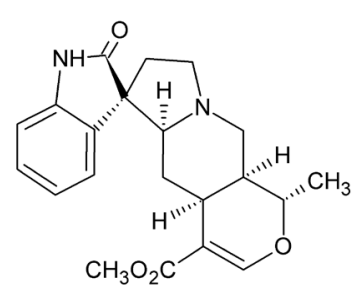

(5) Pteropodine

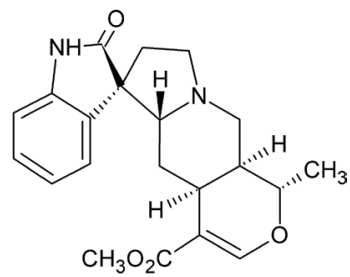

(2) Uncarine F

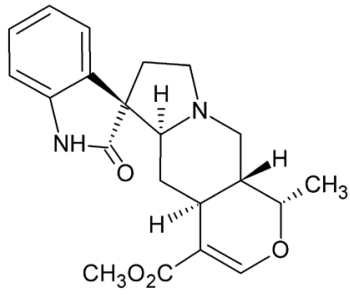

(4) Isomitraphylline

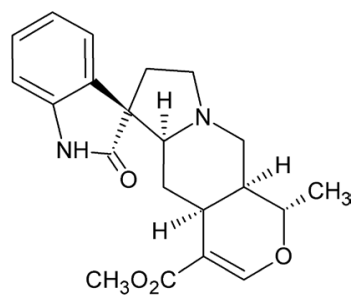

(6) Isopteropodine
Figure 1. Structures of pentacyclic oxindole alkaloids present in the UT extract. 
with $\mathrm{PCL}$, since the isopteropodine $\mathrm{EE}$ in the nanoparticle UT-PLGA was almost four times higher than the speciophylline EE.

From the size distribution analysis, Np UT-PCL presented a significantly higher mean diameter than Np UT-PLGA (Table II). This can be attributed to the higher polymer concentration in the $\mathrm{Np}$ UT-PCL suspension (150 mg/8.5 mL) than Np UTPLGA (58 mg/7 mL). In addition, the PCL organic solution displayed a higher viscosity, which often generates larger nanoparticles than the less viscous PLGA organic solutions, even at the same polymer concentration (Ubrich et al. 2004). When compared to unloaded nanoparticles, the mean diameters were not significantly different, which further suggests that the size was mainly influenced by polymer concentration and the resulting viscosity of the organic phase viscosity, rather than the entrapment process. The low initial mass of alkaloids added to the system probably minimized its contribution to the size of the nanoparticles. No significant differences were observed in the polydispersity index and both presented as spherical shapes in the morphological analysis (Figure 2), with mean diameters measured by TEM consistent with the DLS measurements.
The nanoparticles generated with PCL (Np $P C L$ and Np UT-PCL) had a nearly neutral zeta potential (ZP), which was expected since the PCL polymeric structure has no charged groups. In contrast, PLGA nanoparticles were negatively charged and presented reduced absolute values of zeta potential. PLGA nanoparticles often shows ZP values near -25 mV (Bohrey et al. 2016, Chourasiya et al. 2015, Martín-Banderas et al. 2012), even considering the use of Resomer ${ }^{\circledR}$ RG504, which is an end-caped PLGA with fewer free carboxylic acid end-groups. This suggests that the zeta potential of Np PLGA may have been affected by other components, such as the phosphate buffer in the aqueous phase, leading to the slightly negative ZP value. This effect was previously reported for PLGA nanoparticles that also involved the use of a phosphate buffer in the aqueous phase (Song et al. 2008). The ZP of Np UT-PLGA was significantly higher than the unloaded Np PLGA, which suggests that one or more components of the UT extract affected the surface charge of PLGA nanoparticles. Interestingly, the ZP of nanoparticles formed from PCL was not affected by UT extract.

Table II. Mean diameter, polydispersity index (PI), zeta potential, entrapment efficiency (EE) and drug loading (DL) of polymeric nanoparticles with and without UT extract.

\begin{tabular}{|c|c|c|c|c|}
\hline Nanoparticle characteristic & Np UT-PCL & Np UT-PLGA & Np PCL & Np PLGA \\
\hline Mean diameter $(\mathbf{n m}) *$ & $247.3 \pm 9.9 \mathrm{a}$ & $107.4 \pm 3.0 \mathrm{~b}$ & $239.3 \pm 10.6 \mathrm{a}$ & $115.2 \pm 10.4 \mathrm{~b}$ \\
\hline $\mathbf{P I}^{*}$ & $0.062 \pm 0.0^{5} 5 \mathrm{a}$ & $0.164 \pm 0.0^{5} 6 \mathrm{a}$ & $0.072 \pm 0.0^{5} 0 \mathrm{a}$ & $0.132 \pm 0.0^{6} 6 \mathrm{a}$ \\
\hline Zeta potential (mV)* & $-0.86 \pm 0 .{ }^{2} 7 \mathrm{a}$ & $-4.07 \pm 0.8^{2} \mathrm{~b}$ & $-0.84 \pm 0 .{ }^{3} 9 \mathrm{a}$ & $-1.31 \pm 1 .{ }^{2} 8 \mathrm{a}$ \\
\hline 'EE (\%)** $^{* *}$ & $81.6 \pm 0.7 \mathrm{a}$ & $64.6 \pm 2.0 \mathrm{~b}$ & $\mathrm{n} / \mathrm{a}$ & $\mathrm{n} / \mathrm{a}$ \\
\hline DL (\%)** & $0.76 \pm 0.006^{\mathrm{a}}$ & $1.56 \pm 0.048^{\mathrm{b}}$ & $\mathrm{n} / \mathrm{a}$ & $\mathrm{n} / \mathrm{a}$ \\
\hline
\end{tabular}

Results are expressed as mean \pm standard deviation $(n=3)$; Means with different letters presented significant differences (*ANOVA Tukey's test or **Student's t test, $\alpha=0.05$ ); n/a: not applied; ' ${ }^{*}$ Entrapment efficiency of total alkaloids, calculated using the sum of the six UT POA. 
Table III. Entrapment efficiency found for each UT alkaloid loaded into the polymeric nanoparticles.

\begin{tabular}{|c|c|c|c|}
\hline \multirow{2}{*}{$\begin{array}{c}\text { Alkaloid } \\
\text { (POA) }\end{array}$} & Initial mass $(\mathbf{m g})$ & Np UT-PCL & 'Entrapment Efficiency (\%) \\
\cline { 3 - 4 } & & $67.0 \pm 0.6$ & $21.3 \pm 5.5$ \\
\hline Speciophylline & 0.015 & $77.3 \pm 0.2$ & $46.9 \pm 3.0$ \\
\hline Uncarine F & 0.065 & $71.1 \pm 0.4$ & $53.8 \pm 2.0$ \\
\hline Mitraphylline & 0.291 & $82.5 \pm 1.0$ & $57.6 \pm 1.8$ \\
\hline Isomitraphylline & 0.329 & $84.7 \pm 0.9$ & $66.6 \pm 1.6$ \\
\hline Pteropodine & 0.362 & $90.0 \pm 0.7$ & $81.2 \pm 2.3$ \\
\hline Isopteropodine & 0.338 & \\
\hline
\end{tabular}

Results are expressed as mean \pm standard deviation $(n=3) ;{ }^{1}$ Calculated using the loaded mass and the initial mass of each POA
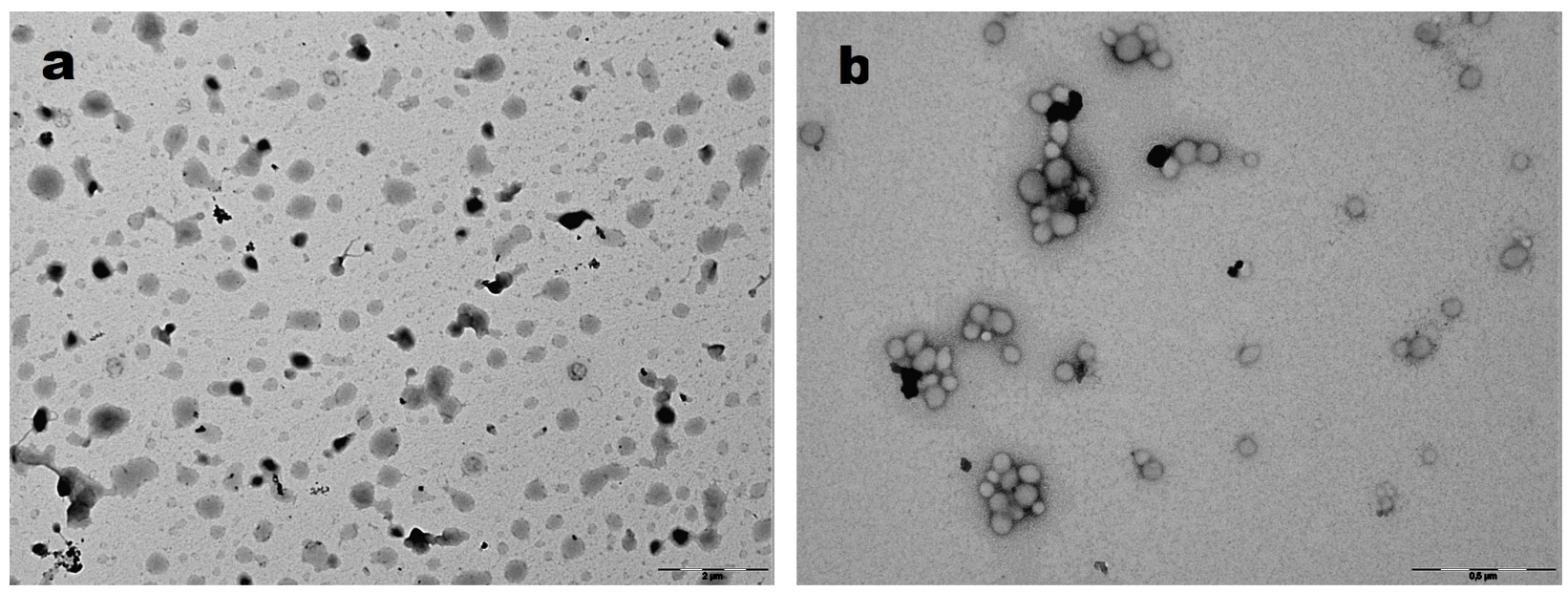

Figure 2. Electron micrographs of UT extract loaded polymeric nanoparticles. Transmission electron microscopy images from $5 \%$ uranium acetate-stained suspensions of (a) Np UT-PCL and (b) Np UT-PLGA. Scale bar in panel a is $2 \mu \mathrm{m}$ and $0.5 \mu \mathrm{m}$ in panel b.

\section{Nanoparticles in vitro stability}

Despite the Low ZP values, both Np UT-PLGA and Np UT-PCL were able to maintain a constant size distribution for a minimum of one week, indicating that the stability of the nanoparticles was not singularly dependent on a raised zeta potential value. Nanoparticles UT-PCL were stable for up to 25 days at $25^{\circ} \mathrm{C}$, as they showed no significant variations in the particles mean diameter during this period (Figure 3), while the blank nanoparticles Np-PCL maintained the mean diameter for even longer time periods, suggesting that the UT extract components influenced the stability of the size of the nanoparticles. On the other hand, the Np UTPLGA showed a reduced size stability compared to Np UT-PCL and presented a significant rise in the mean diameter on the seventh day of analysis. 


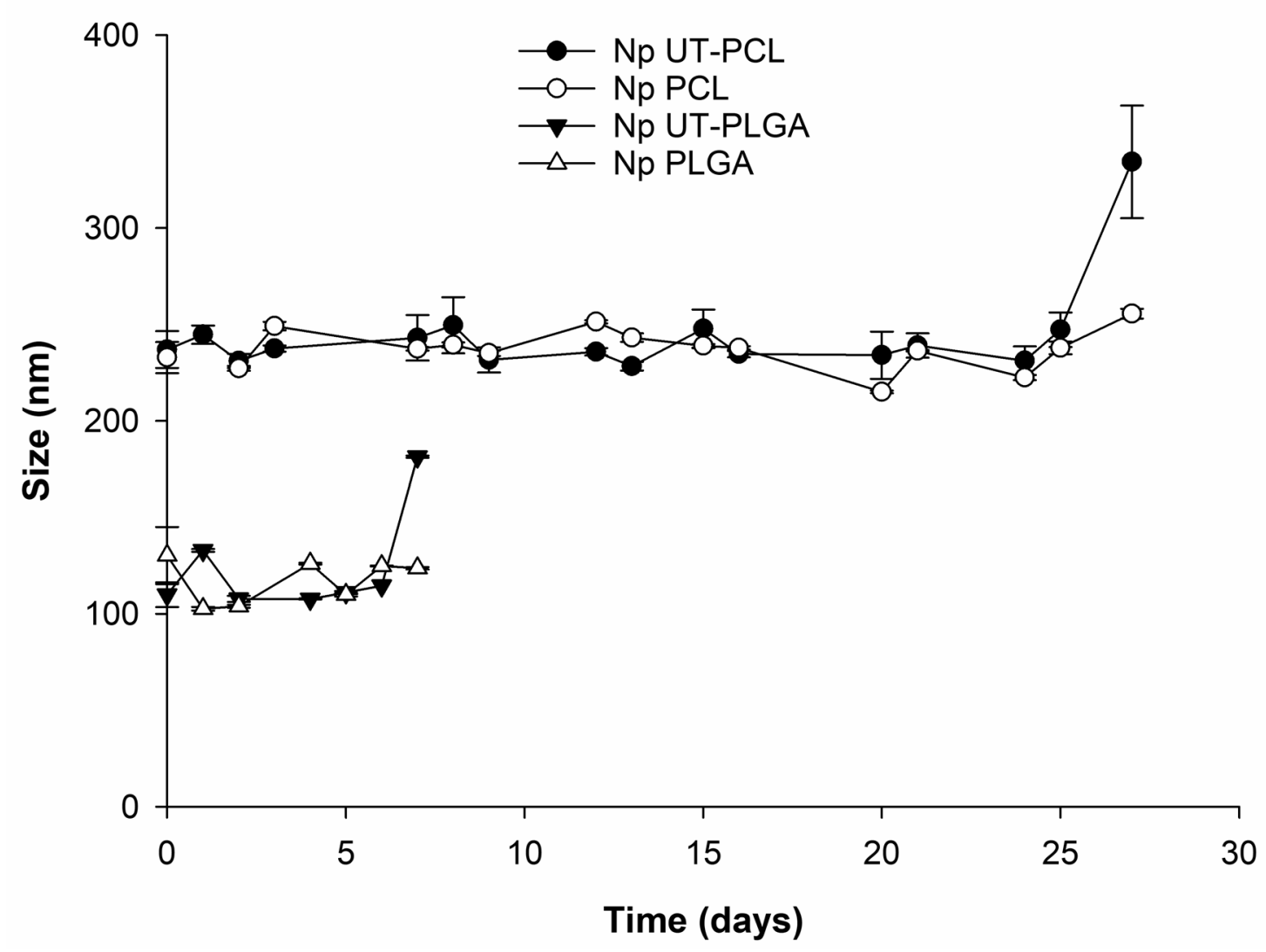

Figure 3. Alterations in nanoparticle size over time. Particle size measurements of polymeric nanoparticles unloaded (Np PCL and Np PLGA) and loaded with UT extract (Np UT-PCL and Np UT-PLGA) maintained at $25^{\circ} \mathrm{C}$ as function of time. Data represents mean $\pm S D(n=4)$.

\section{In vitro release study}

Sustained release is one of the main advantages provided by biodegradable polymers like PCL and PLGA, since nanoparticles formulated with these polymers are able to release the encapsulated drug within days, weeks or even months (Kumari et al. 2010, Woodruff \& Hutmacher 2010). Both formulations presented an initial burst release. During the first 18 hours, Np UT-PCL released about $33 \%$ of the alkaloids, while Np UT-PLGA released about 46\% (Figure 4). This burst effect could be due to the absorption of alkaloids onto the outer surface of the nanoparticles. It could also be a result of the procedure used for the release study. Considering that the whole nanoparticle formulation was added to the dialysis bag, including any non-entrapped alkaloids dissolved in the aqueous phase, the burst release could be partially attributed to the rapid diffusion of the non-entrapped alkaloids through the dialysis membrane to the release medium. Indeed, the burst release was higher for Np UT-PLGA, which presented a lower EE and, therefore, had a higher concentration of nonentrapped alkaloids dispersed in the aqueous phase. The initial burst release, as the observed for Np UT-PCL and Np UT-PLGA, is a frequent event in drug release studies from nanoparticles loaded with natural compounds and some works have reported an initial burst release around 30\% (Stecanella et al. 2013, Yin et al. 2012) or even $50 \%$ in the first 12 hours of the study (Yusuf et al. 2012, Li et al. 2010, Shao et al. 2009). 


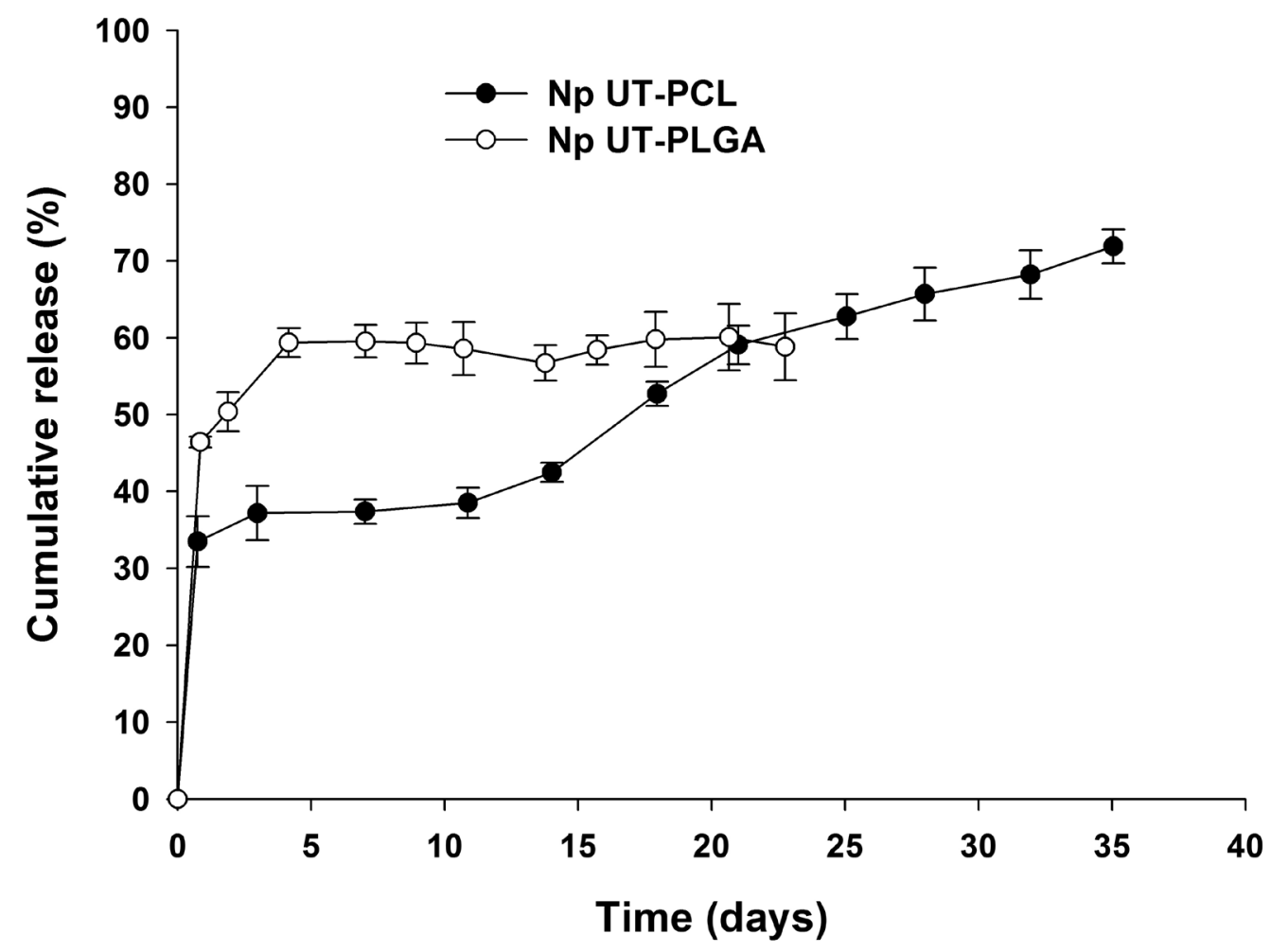

Figure 4. In vitro release profile of UT alkaloids from the polymeric nanoparticles. Np UT-PCL and Np UT-PLGA were contained in a dialysis bag and UT components in the aqueous sink medium were quantified by HPLC. Data are expressed as mean \pm standard deviation $(n=4)$.

Np UT-PCL presented a much slower delivery rate, releasing about $60 \%$ of the alkaloids in 20 days, while Np UT-PLGA released the same amount in five days (Figure 4). The release of small drugs from biodegradable matrix is controlled by polymer degradation and matrix diffusion (Li et al. 2008). PCL has a slower degradation rate and a higher glass transition temperature (Tg) compared to PLGA. Higher Tg values are correlated to a decrease in the polymer chain mobility, which impairs drug diffusion (Ubrich et al. 2004, Woodruff \& Hutmacher 2010).

Np UT-PCL presented a three-modal release pattern (Figure 4), with an initial burst release in the first 18 hours, following a lag period of 15 days, where low or no release occurred, and then a third release period that resulted in $70 \%$ of the alkaloids being released in 35 days. This profile could be explained by the bulk degradation mechanism of a PCL matrix (Woodruff \& Hutmacher 2010, Li et al. 2008). In the lag period, water molecules penetrate the polymer matrix and hydrolyze the chains, which generates acid by-products and results in a low pH environment that stimulates an autocatalytic process. As the oligomers produced during this degradation process are sufficiently small, they diffuse through the polymer matrix into the external medium, as well as the alkaloids, resulting in the third release period.

Np UT-PLGA did not show any additional release after the fifth day of analysis, maintaining the alkaloids release at $60 \%$ over more than 20 days. Agglomeration was observed for these nanoparticles, with a raise in the mean diameter after one week (Figure 3). This agglomeration could reduce the matrix pathways for the alkaloid diffusion and can impair the release of entrapped molecules from nanoparticles ( $\mathrm{Li}$ et al. 2008). 


\section{Cytotoxicity on PC cell lines}

We evaluated the cellular response of two human PC cell lines (LNCaP and DU145) following treatment with UT samples diluted in culture medium (Np UT-PCL, Np UT-PLGA, Np PCL, Np PLGA or UT Sol, PVA Sol, Lutrol Sol). Initially, we analyzed the cell viability by the MTT colorimetric assay by treating the cells at $80 \%$ confluence with concentrations ranging from 4.0 to $20.0 \mathrm{mg} /$ $\mathrm{mL}$ of alkaloids over $72 \mathrm{~h}$. We observed that UT solutions were able to reduce cell viability of the PC cell lines LNCaP and DU145 in a time and concentration-dependent manner (Figure 5). The DU145 cells were more sensitive to UT solutions at higher concentrations than LNCaP cells. These results are consistent with those reported for an Uncaria rhynchophylla extract, which was not able to inhibit the growth of LNCaP cells by more than 50\% (Shoemaker et al. 2005). It is also worth noting that the higher activity of UT solutions against DU145 cells (IC50 $=15.7 \mathrm{mg} / \mathrm{mL}$ of total alkaloids, at 72h) was expected, since the major POAs in the UT solution pteropodine and isopteropodine, had previously shown activity against on both androgen-independent PC cells DU145 (Lee et al. 1999) and PC3 cells (Fujita et al. 2009).

Nanostructured systems have been extensively used to potentiate the activity of anti-tumor agents due to their ability to target entrapped substances to tumor tissues. It has been documented that smaller nanoparticles have better cellular uptake and, consequently, often shows higher activity in cytotoxicity assays (Nair et al. 2012, Rocha et al. 2011). Nanoparticles loaded with UT extract (Np UT-PCL and Np UTPLGA) reduced the viability of both LNCaP and DU145 cells (Figure 6). Unloaded nanoparticles (Np PCL and Np PLGA) had no measurable negative effect on the cellular survival of these cells (Figure 6b). Interestingly, Np UT-PLGA presented a significant higher activity in DU145

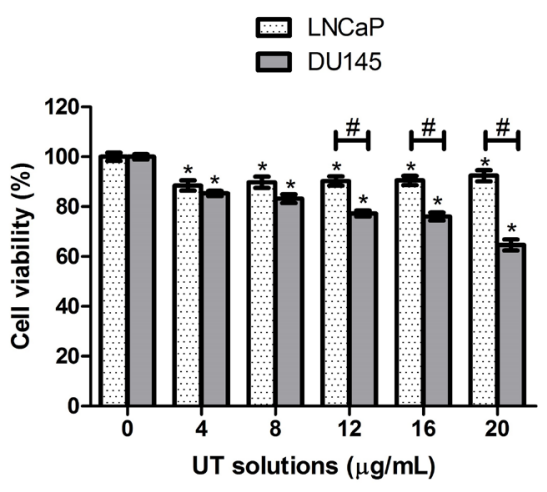

(a)

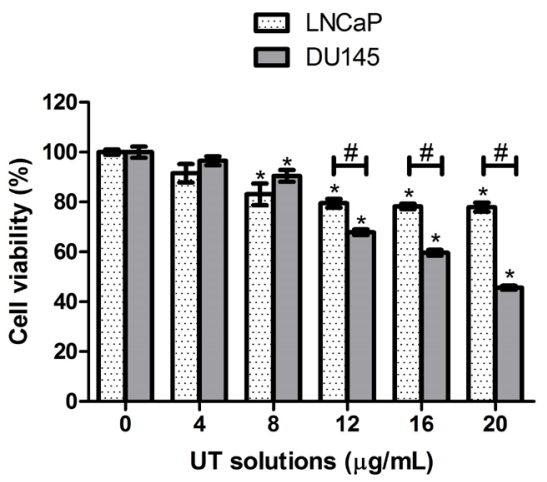

(b)

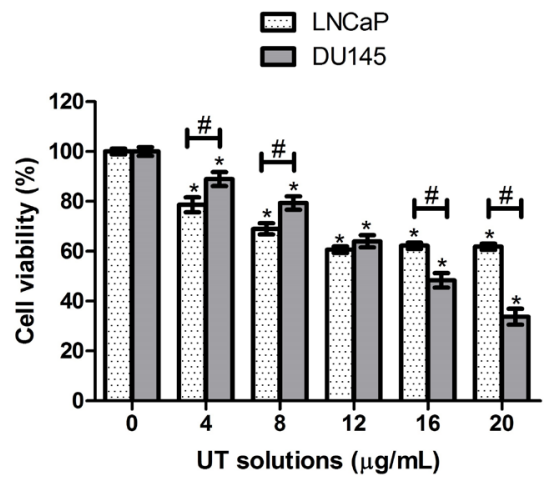

(c)

Figure 5. Viability of LNCaP and DU145 cells exposed to UT extract. Cultures of the human PC cells were maintained for $24 \mathrm{~h} \mathrm{(a),} 48 \mathrm{~h} \mathrm{(b)}$ and $72 \mathrm{~h}(\mathrm{c})$ with increasing concentrations of UT extract solution and assessed by the MTT assay. Values are the mean \pm SEM $(n=18)$. * Significant difference from the control without UT ( $p<0.05$; One-way ANOVA Dunnett's test). \# Significant difference between LNCaP and DU145 ( $p<$ 0.05; Two-way ANOVA Bonferroni posttests). 
a

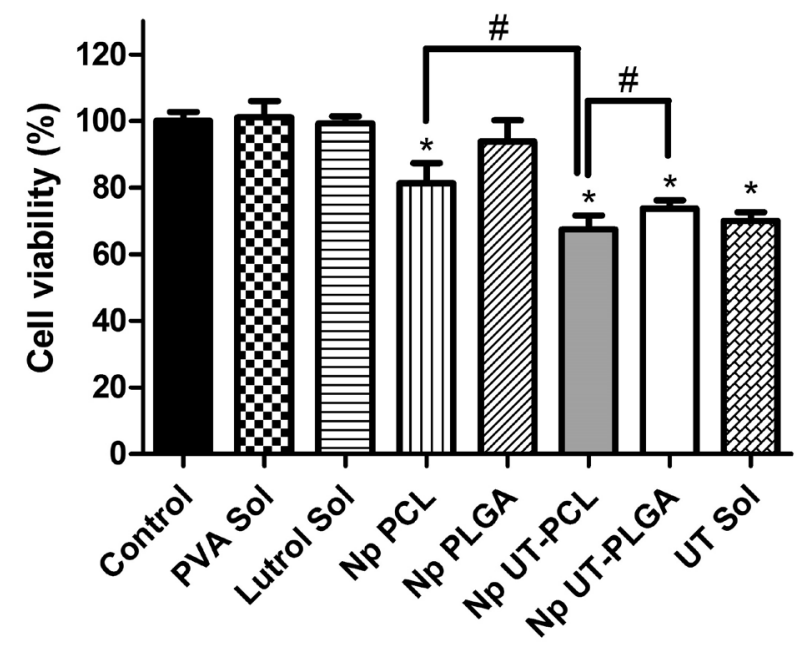

b

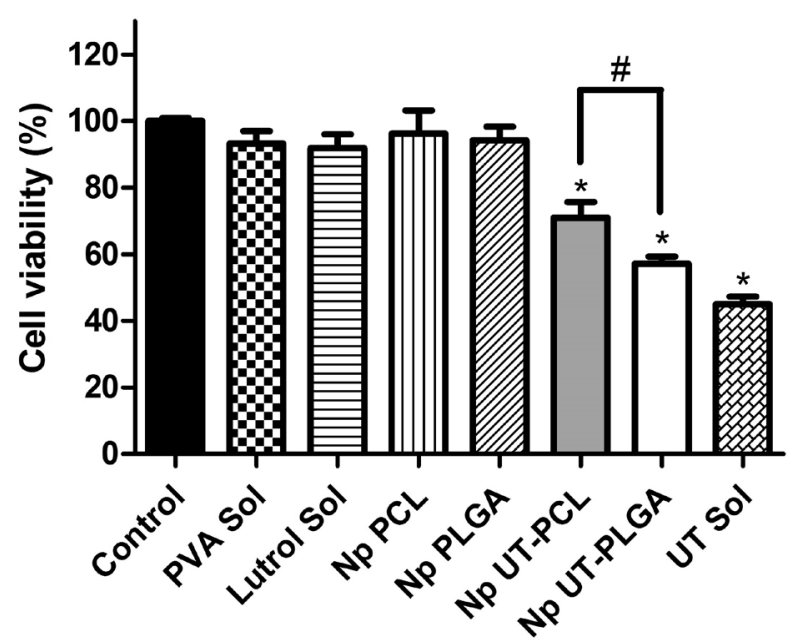

Figure 6. Viability of human prostate cancer cell lines treated with UT extract-loaded nanoparticles. The percent of live LNCaP (a) and DU145 (b) cells at 72h after the treatment with Np UT-PCL and Np UT-PLGA (nanoparticles loaded with UT extract); Np PCL and Np PLGA (nanoparticles without UT extract); UT Sol (aqueous solution of UT extract); PVA sol and Lutrol sol (aqueous solutions of PVA (1\%) and poloxamer $188(0.5 \%)$, respectively). Values represent mean \pm SEM $(n=18)$. *Significant difference from the untreated control $(p<0.05$; One-way ANOVA Dunnett's test). \# Significant difference between formulations $(p<0.05$; Student's $t$ test).

cells compared to Np UT-PCL. This is consistent with the observation with Np UT-PLGA, which has half the diameter of Np UT-PCL (Table II). Another notable difference was that Np UT-PLGA had an $20 \%$ higher total alkaloid concentration $(20.0 \mu \mathrm{g} / \mathrm{mL})$ compared to Np UT-PCL $(16.5 \mu \mathrm{g} /$ $\mathrm{mL}$ ) as well as a higher concentration of free alkaloids due to its lower entrapment efficiency. The total alkaloid concentration difference between the nanoparticle preparations was due in part to the aqueous phase final volume used for each nanoparticle, which was a consequence of the different optimal conditions achieved in the experimental designs (Ribeiro et al. 2013, 2015).

For LNCaP cells, Np UT-PCL showed a higher activity than Np UT-PLGA (Figure 6a). LNCaP cells also displayed sensitivity to unloaded Np PCL, which caused some cell inhibition and could have contributed to the higher activity of Np UTPCL. This was unexpected based on the results reported by Sanna et al. (2015) where unloaded
PCL nanoparticles did not show any effect on LNCaP cells. This difference can be explained by their use of a lower PCL concentration (47.5 $\mathrm{mg} / 20 \mathrm{~mL}$ ), which is nearly 8 -fold lower than the Np PCL suspension in the present work (150 mg/8.5 mL). It does suggest that polymer concentration can participate in cytotoxicity. $\mathrm{PCL}$ concentrations higher than $1 \mathrm{mg} / \mathrm{mL}$, for example, led to significant cytotoxicity of PCL unloaded nanoparticles against C6 glioblastoma cells (Xin et al. 2010). As PCL is a well-known biocompatible polymer (Woodruff \& Hutmacher 2010), it remains to be determined if our observations of cytotoxicity of PCL are restricted to malignant cells and have a lower effect on normal cells. Considering the mean size of the Np UT-PCL $(247.3 \mathrm{~nm})$ and the expectation that nanoparticles will accumulate in tumor tissues by passive targeting (Gaumet et al. 2008, Singh \& Lillard Jr. 2009), the in vivo behavior could be expected to favor anti-tumor effects rather than toxic effects in other tissues. 
As observed in other studies evaluating the anti-tumor activity of nanoparticle systems loaded with natural substances (Nair et al. 2012, Rocha et al. 2011, Wang et al. 2012), the loaded nanoparticles UT-PCL and UT-PLGA (containing 16.5 and $20.0 \mu \mathrm{g} / \mathrm{mL}$ of total alkaloids, respectively), as well as free UT extract (20.0 $\mu \mathrm{g} / \mathrm{mL}$ of total alkaloids), were able to cause significant reduction in cell viability. During the in vitro cytotoxicity assay (72h), more than $40 \%$ of the alkaloids were still encapsulated in the nanoparticles, as could be seen from the release profile, suggesting the reduction in cell viability was potentiated by loading UT extract into the nanoparticle system. Considering the sizes reached for the Np UT-PCL and Np UTPLGA, between 100 and $250 \mathrm{~nm}$, both should be further explored for the future application to enhance the in vivo anti-tumor effect of UT extract, since tumor tissues have blood vessels with fenestrations varying between 200 and $780 \mathrm{~nm}$ in diameter (Gaumet et al. 2008), thus allowing an accumulation of the active substances present in the UT extract in these tissues.

\section{CONCLUSIONS}

Loading of natural extracts into nanoparticle systems can be a real challenge, since the complex composition of extracts often hinders the entrapment process. The EE values reached for Np UT-PCL and Np UT-PLGA were above $60 \%$. This can be considered fairly high for the loading of a plant extract and indicates that the polymers chosen displayed a suitable entrapment of the alkaloids despite the presence of many other components in the UT extract. This is the first study to report on the in vitro anti-tumor activity of polymeric NPs loaded with UT extract against LNCaP and DU145 prostate cancer cell lines. The results strongly suggest that these NPs have the potential to provide a promising alternative to enhance the anti-cancer activity of UT extract.

\section{Acknowledgments}

The authors wish to thank the Herbarium Laboratório Botânico Ltda. and EngePol/COPPE/UFRJ and Dr William Provance Jr. for the English review. This work was supported by Fundação de Amparo à Pesquisa do Estado do Rio de Janeiro (FAPERJ) and Coordenação de Aperfeiçoamento de Pessoal de Nivel Superior (CAPES), Edital CAPES Nanobiotecnologia 2008.

\section{REFERENCES}

ARAÚJO MCS, FARIAS IL, GUTIERRES J, DALMORA SL, FLORES N, FARIAS J, CRUZ I, CHIESA J, MORSCH VM \& SCHETINGER MRC. 2012. Uncaria tomentosa - adjuvant treatment for Breast Cancer: clinical trial. Evid Based Complement Alternat Med: Article ID 676984.

BERTOL G, FRANCO L \& OLIVEIRA BH. 2012. HPLC analysis of oxindole alkaloids in Uncaria tomentosa: sample preparation and analysis optimization by factorial design. Phytochem Anal 23: 143-151.

BHARALI DJ, SIDDIQUI IA, ADHAMI VM, CHAMCHEU JC, ALDAHMASH AM, MUKHTAR H \& MOUSA SA. 2011. Nanoparticle Delivery of Natural Products in the Prevention and Treatment of Cancers: Current Status and Future Prospects. Cancers 3: 4024-4045.

BOHREY S, CHOURASIYA V \& PANDEY A. 2016. Preparation, Optimization by $2^{3}$ Factorial Design, Characterization and In Vitro Release Kinetics of Lorazepam Loaded PLGA Nanoparticles. Polym Sci Ser A58: 975-986.

BONIFÁCIO BV, DA SILVA PB, RAMOS MAS, NEGRI KMS, BAUAB TM \& CHORILLI M. 2014. Nanotechnology-based drug delivery systems and herbal medicines: a review. Int J Nanomedicine 9: 1-15.

CHOURASIYA V, BOHREY S \& PANDEY A. 2015. Hydrochlorothiazide Containing PLGA Nanoparticles: Design, Characterization, In_Vitro Drug Release and Release Kinetic Study. Polym Sci Ser B 57: 645-653.

DREIFUSS AA, BASTOS-PEREIRA AL, AVILA TV, SOLEY BS, RIVERO AJ, AGUILAR JL \& ACCO A. 2010. Antitumoral and antioxidant effects of a hydroalcoholic extract of cat's claw (Uncaria tomentosa) (Willd. Ex Roem. \& Schult) in an in vivo carcinosarcoma model. J Ethnopharmacol 130: 127-133. 
DREIFUSS AA ET AL. 2013. Uncaria tomentosa exerts extensive anti-neoplastic effects against the Walker-256 tumour by modulating oxidative stress and not by alkaloid activity. PLoS One 8: e54618.

FAZIO AL, BALLÉN D, CESARI IM, ABAD MJ, ARSENAK M \& TAYLOR P. 2008. An ethanolic extract of Uncaria tomentosa reduces inflammation and B16-BL6 melanoma growth in C57BL/ 6 mice. Bol latinoam Caribe Plantas Med Aromat 7: 217-224.

FUJITA Y ET AL. 2009. Antitumor activity and mode of action of pentacyclic oxindole alkaloids from Uncaria tomentosa. Cancer Res 69: Abstract nr 2671.

GAUMET M, VARGAS V, GURNY R \& DELIE F. 2008. Nanoparticles for drug delivery: the need for precision in reporting particle size parameters. Eur J Pharm Biopharm 69: 1-9.

GIMÉNEZ DG, PRADO EG, RODRÍGUEZ TS, ARCHE AF \& DE LA PUERTA R. 2010. Cytotoxic Effect of the Pentacyclic Oxindole Alkaloid Mitraphylline Isolated from Uncaria tomentosa Bark on Human Ewings Sarcoma and Breast Cancer Cell Lines. Planta Med 76: 133-136.

HEITZMAN ME, NETO CC, WINIARZ E, VAISBERG AJ \& HAMMOND GB. 2005. Ethnobotany, phytochemistry and pharmacology of Uncaria (Rubiaceae). Phytochemistry 66: 5-29.

KAISER S, CARVALHO ÂR, PITTOL V, DIETRICH F, MANICA F, MACHADO MM, DE OLIVEIRA LF, OLIVEIRA BATTASTINI AM \& ORTEGA GG. 2016. Genotoxicity and cytotoxicity of oxindole alkaloids from Uncaria tomentosa (cat's claw): Chemotype relevance. J Ethnopharmacol 189: 90-98.

KUMARI A, YADAV SK \& YADAV SC. 2010. Biodegradable polymeric nanoparticles based drug delivery systems. Colloids Surf B Biointerfaces 75: 1-18.

KUMARI P, GHOSH B \& BISWAS S. 2016. Nanocarriers for cancer-targeted drug delivery. J Drug Target 24: 179-191.

LEE KK, ZHOU BN, KINGSTON DG \& VAISBERG AJ \& HAMMOND GB. 1999. Bioactive indole alkaloids from the bark of Uncaria guianensis. Planta Med 65: 759-760.

LI J, JIANG G \& DING F. 2008. The Effect of $\mathrm{pH}$ on the Polymer Degradation and Drug Release from PLGA-mPEG Microparticles. J Appl Polym Sci 109: 475-482.

LI X, ZHEN D, LU X, XU H, SHAO Y, XUE Q, HU Y, LIU B \& SUN W. 2010. Enhanced cytotoxicity and activation of ROSdependent c-Jun NH2-terminal kinase and caspase-3 by low doses of tetrandrine-loaded nanoparticles in Lovo cells - A possible Trojan strategy against cancer. Eur J Pharm Biopharm 75: 334-340.

MARTÍN-BANDERAS L, ÁLVAREZ-FUENTES J, DURÁN-LOBATO M, PRADOS J, MELGUIZO C, FERNÁNDEZ-ARÉVALO M \& ÁNGELES HOLGADO M. 2012. Cannabinoid derivate-loaded PLGA nanocarriers for oral administration: formulation, characterization, and cytotoxicity studies. Int J Nanomedicine 7: 5793-5806.

MEDJAKOVIC S, HOBIGER S, ARDJOMAND-WOELKART K, BUCAR F \& JUNGBAUER A. 2016. Pumpkin seed extract: Cell growth inhibition of hyperplastic and cancer cells, independent of steroid hormone receptors. Fitoterapia 110: 150-156.

MIRANDA RR \& FREITAS JJS. 2008. The anti-proliferative effects of the ethanolic extract of Uncaria tomentosa in Ehrlich ascitic carcinoma. Rev Para Med 22: 17-22.

NAIR KL, THULASIDASAN AKT, DEPA G, ANTO RJ \& KUMAR GSV. 2012. Purely aqueous PLGA nanoparticulate formulations of curcumin exhibit enhanced anticancer activity with dependence on the combination of the Carrier. Int J Pharm 425: 44-52.

PARK KH, YIN J, YOON KH, HWANG YJ \& LEE MW. 2016. Antiproliferative Effects of New Dimeric Ellagitannin from Cornus alba in Prostate Cancer Cells Including Apoptosis-Related S-Phase Arrest. Molecules 21: 137.

PILARSKI R, FILIP B, WIETRZYK J, KURAŚ M \& GULEWICZ K. 2010. Anticancer activity of the Uncaria tomentosa (Willd.) DC. preparations with different oxindole alkaloid composition. Phytomedicine 17: 1133-1139.

PRADO EG, GIMENEZ MDG, VÁZQUEZ RP, SÁNCHEZ JLE \& RODRÍGUEZ MTS. 2007. Antiproliferative effects of mitraphylline, a pentacyclic oxindole alkaloid of Uncaria tomentosa on human glioma and neuroblastoma cell lines. Phytomedicine 14: 280-284.

RAO KVK, SCHWARTZ SA, NAIR HK, AALINKEEL R, MAHAJAN S, CHAWDA R \& NAIR MPN. 2004. Plant derived products as a source of cellular growth inhibitory phytochemicals on PC-3M, DU145 and LNCaP prostate cancer cell lines. Curr Sci 87: 1585-1588.

RIBEIRO AF, DE OLIVEIRA REZENDE RL, CABRAL LM \& DE SOUSA VP. 2013. Poly-e-caprolactone nanoparticles loaded with Uncaria tomentosa extract: preparation, characterization, and optimization using the Box-Behnken design. Int J Nanomedicine 8: 431-442.

RIBEIRO AF, FERREIRA CTG, DOS SANTOS JF, CABRAL LM \& DE SOUSA VP. 2015. Design of experiments for the development of poly(d,l-lactide-co-glycolide) nanoparticles loaded with Uncaria tomentosa. J Nanopart Res 17: 69.

ROCHA S, GENERALOV R, PEREIRA MC, PERES I, JUZENAS P \& COELHO MAN. 2011. Epigallocatechin gallate-loaded polysaccharide nanoparticles for prostate cancer chemoprevention. Nanomedicine 6: 79-87.

RUSSELL PJ \& KINGSLEY EA. 2003. Human Prostate Cancer Cell Lines. In: Russell PJ, Jackson P \& Kingsley EA (Eds), 
Methods in Molecular Medicine. Totowa: Humana Press Inc, vol. 81.

SANNA V, CHAMCHEU JC, PALA N, MUKHTAR $H$, SECHI M \& SIDDIQUI IA. 2015. Nanoencapsulation of natural triterpenoid celastrol for prostate cancer treatment. Int J Nanomedicine 10: 6835-6846.

SANNA V, SIDDIQUI IA, SECHI M \& MUKHTAR H. 2013. Nanoformulation of natural products for prevention and therapy of prostate cancer. Cancer Lett 334: 142-151.

SHAO J, LI X, LU X, JIANG C, HU Y, LI Q, YOU Y \& FU Z. 2009. Enhanced growth inhibition effect of Resveratrol incorporated into biodegradable nanoparticles against glioma cells is mediated by the induction of intracellular reactive oxygen species levels. Colloids Surf B Biointerfaces 72: 40-47.

SHOEMAKER M, HAMILTON B, DAIRKEE SH, COHEN I \& CAMPBELL MJ. 2005. In vitro Anticancer Activity of Twelve Chinese Medicinal Herbs. Phytother Res 19: 649-651.

SIEGEL RL, MILLER KD \& JEMAL A. 2017. Cancer Statistics. CA Cancer J Clin 67: 7-30.

SINGH R \& LILLARD JR JW. 2009. Nanoparticle-based targeted drug delivery. Exp Mol Pathol 86: 215-223.

SONG X, ZHAO Y, WU W, BI Y, CAI Z, CHEN Q, LI Y \& HOU S. 2008. PLGA nanoparticles simultaneously loaded with vincristine sulfate and verapamil hydrochloride: Systematic study of particle size and drug entrapment efficiency. Int J Pharm 350: 320-329.

STECANELLA LA, TAVEIRA SF, MARRETO RN, VALADARES M \& VIEIRA MSV. 2013. Development and characterization of PLGA nanocapsules of grandisin isolated from Virola surinamensis: in vitro release and cytotoxicity studies. Braz J Pharmacog 23: 153-159.

STONE KR, MICKEY DD, WUNDERLI H, MICKEY GH \& PAULSON DF. 1978. Isolation of a human prostate carcinoma cell line (DU 145). Int J Cancer 21: 274-281.

STUPPNER H, STURM S \& KONWALINKA G. 1992. Capillary electrophoretic analysis of oxindole alkaloids from Uncaria tomentosa. J Chromatogr 609: 375-380.

SULTANA S, KHAN MR, KUMAR M, KUMAR S \& ALI M. 2013. Nanoparticles-mediated drug delivery approaches for cancer targeting: a review. J Drug Target 21: 107-125.

UBRICH N, BOUILLOT P, PELLERIN C, HOFFMAN M \& MAINCENT P. 2004. Preparation and characterization of propranolol hydrochloride nanoparticles: a comparative study. J Control Release 97: 291-300.

URDANIBIA I, MICHELANGELI F, RUIZ M-C, MILANO B \& TAYLOR P. 2013. Anti-inflammatory and antitumoural effects of Uncaria guianensis bark. J Ethnopharmacol 150: 1154-1162.

VELDSCHOLTE J, RIS-STALPERS C, KUIPER GG, JENSTER G, BERREVOETS C, CLAASSEN E, VAN ROOIJ HC, TRAPMAN J, BRINKMANN AO \& MULDER E. 1990. A mutation in the ligant binding domain of the androgen receptor of human LNCaP cells affects steroid binding characteristics and response to anti-androgens. Biochem Biophys Res Commun 173: 534-540.

WANG S, CHEN T, CHEN R, HU Y, CHEN M \& WANG Y. 2012. Emodin loaded solid lipid nanoparticles: Preparation, characterization and antitumor activity studies. Int J Pharm 430: 238-246.

WOODRUFF MA \& HUTMACHER DW. 2010. The return of a forgotten polymer - Polycaprolactone in the $21^{\text {st }}$ century. Prog Polym Sci 35: 1217-1256.

XIN H, CHEN L, GU J, REN X, WEI A, LUO J, CHEN Y, JIANG X, SHA X, FANG X. 2010. Enhanced anti-glioblastoma efficacy by PTXloaded PEGylated poly(e-caprolactone) nanoparticles: In vitro and in vivo evaluation. Int J Pharm 402: 238-247.

YIN P, WANG Y, QIU YY, HOU L, LIU X, QIN J, DUAN Y, LIU P, QIU M \& LI Q. 2012. Bufalin-loaded mPEG-PLGA-PLL-CRGD nanoparticles: preparation, cellular uptake, tissue distribution, and anticancer activity. Int J Nanomedicine 7: 3961-3969.

YUSUF M, KHAN RA, KHAN M \& AHMED B, 2012. Plausible antioxidant biomechanics and anticonvulsant pharmacological activity of brain-targeted $\beta$-carotene nanoparticles. Int J Nanomedicine 7: 4311-4322.

ZHANG Y, SEERAM NP, LEE R, FENG L \& HEBER D. 2008. Isolation and Identification of Strawberry Phenolics with Antioxidant and Human Cancer Cell Antiproliferative Properties. J Agric Food Chem 56: 670-675.

\section{How to cite}

RIBEIRO AF, SANTOS JF, MATTOS RR, BARROS EGO, NASCIUTTI LE, CABRAL LM \& SOUSA VP. 2020. Characterization and in vitro antitumor activity of polymeric nanoparticles loaded with Uncaria tomentosa extract. An Acad Bras Cienc 92: e20190336. DOI 10.1590/0001-3765202020190336.

Manuscript received on March 25, 2019; accepted for publication on August 5, 2019

\section{ANA F. RIBEIRO ${ }^{1,2}$}

https://orcid.org/0000-0002-6887-0577

\section{JULIANA F. SANTOS ${ }^{2}$}

https://orcid.org/0000-0001-8219-7123 
RÔMULO R. MATTOS ${ }^{3}$

https://orcid.org/0000-0003-1036-3764

ELIANE G.O. BARROS ${ }^{3}$

https://orcid.org/0000-0002-0020-6653

\section{LUIZ EURICO NASCIUTTI ${ }^{3}$}

https://orcid.org/0000-0002-2597-793X

\section{LÚCIO M. CABRAL ${ }^{1}$}

https://orcid.org/0000-0002-4550-5729

\section{VALERIA P. DE SOUSA ${ }^{1}$}

https://orcid.org/0000-0003-1589-0846

${ }^{1}$ Departamento de Fármacos e Medicamentos, Faculdade de Farmácia, Universidade Federal do Rio de Janeiro, Av. Carlos Chagas Filho, 373, CCS, 21941-902 Rio de Janeiro, RJ, Brazil

${ }^{2}$ Faculdade de Farmácia, Federal Institute of Education, Science and Technology of Rio de Janeiro, Rua Professor Carlos Wenceslau, 343, 21715-000 Rio de Janeiro, RJ, Brazil

${ }^{3}$ Programa de pesquisa em Biologia Celular e do Desenvolvimento, Instituto de Ciências Biomédicas, Universidade Federal do Rio de Janeiro, Av. Carlos Chagas Filho, 373, CCS, 21941-902 Rio de Janeiro, RJ, Brazil

Correspondence to: Valéria Pereira de Sousa

E-mail:valeria@pharma.ufrj.br

\section{Author contributions}

Valeria P. de Sousa and Lúcio M. Cabral conceived of the presented idea and supervised the work. Ana F. Ribeiro was responsible for carry out the experiments and wrote the manuscript. Juliana F. Santos contributed with the in vitro release study. Rômulo R. Mattos and Eliane G. O. Barros carried out the citotoxicity studies. Luiz Eurico Nasciutti supervised the cytotoxicity studies. All authors discussed the results and contributed to the final manuscript.

\section{(cc) BY}

